\title{
Assessment of Weed Flora Composition in Parthenium (Parthenium hysterophorus L.) Infested Area of East Shewa Zone, Ethiopia
}

\author{
Kifle Belachew ${ }^{1}$, Taye Tessema ${ }^{2}$ \\ ${ }^{1}$ Ethiopian Institute of Agricultural Research, Jimma Agricultural Research Center, Jimma, ETHIOPIA \\ ${ }^{2}$ Ethiopian Institute of Agricultural Research, Addis Ababa, ETHIOPIA
}

\begin{abstract}
Field survey on parthenium was conducted at East shewa Zone of Oromiya Regional State, Ethiopia during 2008 cropping season. The objectives of the study was to assess the weed flora composition and plant species that are growing in copetation with parthenium to use those plants as potential biological management options under field condition. Assessment of weed flora composition was carried out in five Kebeles (Farmers Association) of Boset District East Shewa Zone of Oromiya Regional State, Ethiopia. Data on the species composition were recorded and samples of weed flora compositions were collected. The result showed a total of eighty five different herbaceous plant species that were collected and recorded in 63 genera and 24 families. Poaceae (21), Asteraceae (11), Fabaceae (7) and Convolvulaceae (7) were by far the richest taxa and accounted together (55\%) of the entire flora of the study area. The major plant species having higher dominance value were Parthenium hysterophorus (25.6), Cassia tora (6.07), Argemone mexicana (5.83), Xanthium strumarium (4.53), Digitaria abyssinica (3.02) and Cyperus rotundus (2.86). Similarity index values of the species composition among different kebeles ranged from $65 \%$ to $78 \%$ which indicating that weed species compositions in these locations were similar. The diversity and evenness of species declined with increasing spread of parthenium which suggests negative influence that parthenium had on the status of species diversity in the studied area. In conclusion the selected plant species that were found competitive with parthenium based on their abundance and dominance values were Argemone mexicana, Cassia tora, and Xanthium strumarium which were suggested for detailed competition experiment in order to determine their competitiveness with $P$. hysterophorus and will be used for biological management of it.
\end{abstract}

Key words: Competitive, evenness, flora composition, parthenium hysterophorus, plant biodiversity, similarity index

How to Cite: Belachew K and Tessema T. (2015) Assessment of Weed Flora Composition in Parthenium (Parthenium hysterophorus L.) Infested Area of East Shewa Zone, Ethiopia, Malaysian Journal of Medical and Biological Research, 2(2), 105-112.

This article is is licensed under a Creative Commons Attribution-NonCommercial 4.0 International License.

Attribution-NonCommercial (CC BY-NC) license lets others remix, tweak, and build upon work non-commercially, and although the new works must also acknowledge \& be non-commercial.

\section{INTRODUCTION}

Parthenium (Parthenium hysterophorus L). is a herbaceous invasive alien weed belongs to the family Asteraceae. It is believed to be originated from countries around the Gulf of Mexico, and had spread throughout the Southern USA, the Caribbean and Brazil (Navie et al., 2004). From its centre of origin, parthenium had spread to Africa, Australia and Asia during the last five decades (Aneja et al., 1994). Now it has been widely distributed in South and East Africa. As elsewhere in the world (Evans, 1997), parthenium, an alien invasive weed has been threatening the natural and agricultural ecosystems in Ethiopia. There was no concrete evidence so far regarding the introduction of parthenium into Ethiopia. According to farmers around Dire Dawa, parthenium was introduced during the war between Ethiopia and Somalia (1976-1977), in such a way that the Somalian soldiers brought it to Dire Dawa by covering their weapons with parthenium plants and that it was first observed in Dire Dawa area (Taye, 2002).

The weed has been spreading throughout the country after it was first noticed around Dire Dawa in 1980's (Firew et al., 1996; Tamado, 2001). The weed that has been widely spreading to other parts of the country at an alarming rate must have now exerted a substantial impact on the native biodiversity of rangelands and arable lands. Parthenium is so aggressive and devastating that very little and sometimes no other plant species are seen in areas where it has gained dominance (Wittenberg, 2004). Parthenium is widely spread in the range lands and in the cultivable fields of at East Show Zone of Boset district where this study was conducted and its occurrence has been negatively affecting the composition, diversity and vegetation of the area through depleting wealth and biodiversity of the natural plant species.

There is no single control method of parthenium which has been proved satisfactory as each method suffers from one or more limitations. According Bhan et al. (1997) single control method may be inefficient, costly, impracticable, 
environmentaly unsafe and too as only temporary relief. Hence, there is need to adopt an integrated parthenium management approach by amalgamating more than one option. Integrating strong interfering competitor plants as component of integrated parthenium management is the best effective approaches. Use of strong interfering smoother crops and plants for parthenium management is practiced in different countries of the world but which, is not studied under Ethiopian condition. Singh (1997) suggested the use of Cassia uniflora for suppression of parthenium to be effective. Similarly, studies were done on the effect of competitive plants and their density on the growth and flowering of parthenium (Singh, 1997). They found that Abutilon indicum and Cassia sericea reduced dry matter accumulation of parthenium by $70 \%$ and parthenium population by $52 \%$ and $59.3 \%$, respectively (Bhan et al., 1997; Singh, 1997). Several other plants like Tephrosea purpurea, Amaranthus spinosus, Hyptis savolensis, Sida latifolia, Croton sparciflorus and other species of Cassia have been found to suppress parthenium (Singh, 1997). However, some believe that plant bio-agents are weeds and do not deserve to be encouraged and that the allergens in the plant species should also be investigated before they are recommended for parthenium control (Singh, 1997).

Management of parthenium through strong competitive plants are long term and ecologically sound management approach but this has not been given due attention in Ethiopia and no information was available with regard to plant species that grow along with parthenium. According to some observation in some parthenium infested areas of Ethiopia in 2007 of dry season plant species like Xanthium strumarium, Argemone mexicana and Cassia tora were abundantly growing along with parthenium and can out compete it at off season of the year (Personal communication). This observation was not scientifically proved before in our country. That is why my attention was drawn to identification and selection of competitive plant species which grow along with parthenium. Hence, identification of competitive plant species through survey and determination of competitiveness of such plant species with parthenium is an essential step to fill the existing information gap for future implementation of biological control of parthenium by using live competitive plant species for an integrated parthenium management system in Ethiopia. Therefore, the objectives of the study were to assess the weed flora composition in parthenium infested area of Boset District in the East Shewa Zone and to determine frequency, abundance, dominances, species diversity, species richness and species evenness of herbaceous plant species that are growing in competition with parthenium to use those plants as potential biologic al management options.

\section{Materials AND Methods}

\section{DESCRIPTION OF THE STUDY AREA}

The study was conducted at Welenchiti, Boset district of East Shewa Zone, Oromiya Regional State, and it lies between $8^{0} 25^{\prime}-8^{0} 50^{\prime} \mathrm{N}$ and longitude $39^{\circ} 25^{\prime}-39^{\circ} 50^{\prime} \mathrm{E}$ with an altitude ranges of 1100 and 1800 m.a.s.l. It is about 125 $\mathrm{km}$ East of Addis Ababa, capital of the country. The climate condition of the area is semi-arid type. An average total annual rainfall is $850 \mathrm{~mm}$. The highest rainfall was recorded in August $(220 \mathrm{~mm})$ and lowest in December $(4.5 \mathrm{~mm})$. The area receives mean annual rainfall $850 \mathrm{~mm}$ with maximum and minimum temperature of $23.3^{\circ} \mathrm{C}$ and of $18.90^{\circ}$ C, respectively (Debela et al., 2004).

\section{Assessment of Weed Flora Composition in Parthenium Infested Area}

A survey on parthenium distribution and plant species grown was carried out by selected five peasant association (PAs) of Boset district, East Showa Zone. It was conducted right after the main rainy season during September 2008 when the vegetation was to a larger extent at full flowering and vigorous growth stage. The PAs were five priori defined areas namely, Xiyo, Digelu wanga, Tsedecha, Borchota and Tiri Birretii. The Farmers Associations (FAs) were selected based on the level of infestation of parthenium and access to the main road.

For the study, area, which represent the peasant associations were selected. At each selected site, two parallel transects of each one $\mathrm{km}$ length and $500 \mathrm{~m}$ apart from each other and varying in terms of slope, drainage and soil types were established for plant data collection. In each PAs, data was collected from 40 evenly spaced $1 \mathrm{~m} \times 1 \mathrm{~m}$ sample quadrants at every fifty meter from each other. This procedure was adopted for all sampling occasions in each of the five PAs. The numbers of plants were recorded per species in each $1 \mathrm{~m}^{2}$ quadrant. The infestation of parthenium was estimated by counting the number of plants per quadrant and identifying plant species grown along with it following the method used by Yohannes and Taye (1999) with some modification (Taye, 2002).

\section{Data Analysis}

The data on weed species was summarized using the formula described by Taye et al. (1998) as depicted below: Frequency (consistency) is the percentage of sampling units (vegetation registrations) on which a particular weed species is found. It explains as how often a species occurs in the survey area. The frequency is calculated for all species as follows:

\section{$\mathrm{F}=100^{*} \mathrm{X} / \mathrm{N}$}

Where, $\mathrm{F}=$ frequency; $\mathrm{X}=$ number of occurrences of a weed species; $\mathrm{N}=$ sample number

Abundance: population density of weed species expressed as the number of individuals of plants per unit area. 


\section{$\mathbf{A}=\Sigma \mathbf{W} / \mathbf{N}$}

Where, $\mathrm{A}=$ abundance; $\mathrm{W}=$ number of individual species/sample; $\mathrm{N}$ = sample number

Dominance: abundance of a species in relation to total weed abundance.

$$
\mathrm{D}=\mathrm{A}^{*} \mathbf{1 0 0} / \Sigma \mathrm{A}
$$

Where, $\mathrm{D}=$ dominance; $\mathrm{A}=$ abundance; $\Sigma \mathrm{A}=$ total abundance (of all species)

Similarity Index/Community Index: is the similarity of weed communities between different locations.

$$
\mathrm{SI}=100 * \mathrm{Eph} /(\mathrm{Eph}+\mathrm{Epa}+\text { Epub })
$$

Where, SI = Similarity index; Eph = number of species found in both $a$ and $b$; Epa = number of species found in $a$; Epub $=$ number of species found in $b$.

The diversity of the species in vegetation data among the sample sites in the District of the study area were computed using Shannon Diversity Index. Abundance and evenness of the species were accounts in natural environment as shown by the equation below (Shannon and Weaver, 1963) and is used to assess the impact of parthenium on the diversity of herbaceous plant species. The higher value of index of diversity indicates the variability in the type of species and heterogeneity in the community where as the lesser values point to the homogeneity of the community,

$$
\mathrm{H}=\underset{\mathrm{i}=1}{\Sigma} \operatorname{pi} \ln (p i)
$$

Where, $\mathrm{H}=$ Shannon diversity index; $\mathrm{pi}=$ importance value of the $\mathrm{i}^{\text {th }}$ species, $\mathrm{s}=$ total number of species in the sample quadrate

The evenness of species calculated as suggested by Hill, (1973)

$$
\mathrm{E}=\exp (\mathrm{H}) / \ln \mathrm{S}
$$

This index explains how equally abundant each species would be in the plant community and high evenness is a sign of ecosystem health.

\section{Results AND Discussion}

\section{Weed Flora Composition in Parthenium Infested Area of Boset district}

The total of eighty-five different herb species was collected and identified from the surveyed half square kilometer area (Table 1). Of these, eighty-one species were identified on the spot at species level while the other four were differentiated only to the genus level since small seedlings were difficult to identify from closely related species at the time of data collection. These species belong to the genera of Cassia, Chenopodium, Trifolium and Crotalaria.

Among the eighty-five total herbaceous plant species recorded over different PAs , 72 species were found in Xiyoo, 69 in Digelu, 67 in Tri Biretii, 76 in Tsedecha and 70 in Borchota PAs. The herbaceous plant species recorded in different PAs were more or less similar in terms of species composition. Only 7 herbs were recorded in Tedecha, 4 in Borchota, and 1 in Digelu which were not found in other surveyed PAs. The plant species composition noted and their frequency, abundance and dominance characteristics are described (Tables 1-5).

The plant species compositions were distributed in 63 genera with in 24 families. The majority of these, 56 species, were dicotyledonous species while the other 27 species were grasses, and two were sedges (Table 1). The major families, based on the number of taxa were Poaceae (21), Asteraceae (11), Fabaceae (7), Convolvulaceae (7), Euphorbiaceae (5) and Solonaceae (5) (Table 2). These genera accounted for $66 \%$ of the total herbaceous plant species in the study area. These families were also reported to be economically important and common in different parts of the country (Taye and Yohannes, 1998; Firehun and Tamado, 2006). Moreover, these families are very rich in species diversity so it is usual that they contain many plant species. Asteraceae, Poaceae and Fabaceae were also found to be most important in other studies in the tropics (Tamado and Milberg, 2002).

Table 1: Weed Species composition in Boset district of five locations after main (long) rainy season during September 2008

\begin{tabular}{llllcccc}
\hline No & \multicolumn{1}{c}{ Scientific name } & Family & LC & $\mathrm{GH}$ & $\mathrm{F}(\%)$ & $\mathrm{A}\left(\mathrm{No} / \mathrm{m}^{2}\right)$ & $\mathrm{D}(\%)$ \\
\hline 1 & Achyranthes aspera L. & Amaranthaceae & $\mathrm{a}$ & $\mathrm{He}$ & 7.5 & 0.4 & 0.38 \\
2 & Ageratum conyzoides L. & Asteraceae & $\mathrm{a}$ & $\mathrm{He}$ & 10 & 0.46 & 0.43 \\
3 & Agrostis alba L. & Poaceae & $\mathrm{a}$ & $\mathrm{T}$ & 12.5 & 0.36 & 0.34 \\
4 & Amaranthus hybridus L & Amaranthaceae & $\mathrm{a}$ & $\mathrm{He}$ & 20 & 0.9 & 0.86 \\
5 & Amaranthus spinosus L. & Amaranthaceae & $\mathrm{a}$ & $\mathrm{He}$ & 15 & 0.66 & 0.62 \\
6 & Amaranthus deflexus L. & Amaranthaceae & $\mathrm{a}$ & $\mathrm{He}$ & 12.5 & 0.66 & 0.62 \\
7 & Ambrosia psilostachrya DC & Asteraceae & $\mathrm{a}$ & $\mathrm{He}$ & 17.5 & 0.8 & 0.76 \\
8 & Alternanthera sessilis L. & Amaranthaceae & $\mathrm{a}$ & $\mathrm{He}$ & 17.5 & 0.7 & 0.66 \\
9 & Anagalis arvensis L. & Primulaceae & $\mathrm{a}$ & $\mathrm{Hs}$ & 20 & 1.9 & .86 \\
10 & Argemone mexicana Sweet & Papaveriaceae & $\mathrm{a}$ & $\mathrm{He}$ & 47.5 & 5.1 & 5.83
\end{tabular}




\begin{tabular}{|c|c|c|c|c|c|c|c|}
\hline 11 & Artemisia arvensis L. & Asteraceae & a & $\mathrm{He}$ & 15 & 0.8 & 0.76 \\
\hline 12 & Bidens pilosa L & Asteraceae & a & $\mathrm{He}$ & 17.5 & 0.8 & 0.76 \\
\hline 13 & Cassia sp & Fabaceae & a & $\mathrm{He}$ & 15 & 1.06 & 1.03 \\
\hline 14 & Cassia tora L & Fabaceae & a & $\mathrm{He}$ & 55 & 6.36 & 6.07 \\
\hline 15 & Chloris inflata L & Poaceae & a & $\mathrm{T}$ & 17.5 & 0.64 & 0.62 \\
\hline 16 & Chenopodium album L & Chenopodiaceae & a & $\mathrm{He}$ & 20 & 1.26 & 1.49 \\
\hline 17 & Chenopodium sp & Chenopodiaceae & a & $\mathrm{He}$ & 20 & 0.7 & 0.66 \\
\hline 18 & Convolvolus arvensis L & Convolvulaceae & $\mathrm{p}$ & Hc & 22.5 & 0.9 & 0.86 \\
\hline 19 & Crotalaria $\mathrm{sp}$ & Fabaceae & a & $\mathrm{He}$ & 7.5 & 0.9 & 0.57 \\
\hline 20 & Cyperus rotundus L. & Cyperaceae & $\mathrm{p}$ & HR & 45 & 3.3 & 2.68 \\
\hline 21 & Cyperus esculentus L. & Cyperaceae & $\mathrm{p}$ & HR & 30 & 1.16 & 1.1 \\
\hline 22 & Cynodon dactylon L. & Poaceae & $\mathrm{p}$ & HR & 52.5 & 4.16 & 3.97 \\
\hline 23 & $\begin{array}{l}\text { Cynodon nlemfuensis } \\
\text { Vanderyst. }\end{array}$ & Poaceae & $\mathrm{p}$ & Нp & 20 & 0.66 & 0.62 \\
\hline 24 & Datura inoxia Mill. & Solanaceae & a & $\mathrm{He}$ & 20 & 0.26 & 0.2 \\
\hline 25 & Datura stramonium L. & Solanaceae & a & $\mathrm{He}$ & 10 & 0.3 & 0.28 \\
\hline 26 & Desmodium adscendens DC & Fabaceae & a & $\mathrm{He}$ & 12.5 & 0.76 & 0.69 \\
\hline 27 & Dinebra retroflexa Vahl & Poaceae & a & $\mathrm{T}$ & 12.5 & 0.76 & 0.69 \\
\hline 28 & Digitaria abyssinica Stapf & Poaceae & $\mathrm{p}$ & HR & 45 & 4.35 & 4.02 \\
\hline 29 & Digitaria horizontalis Wild & Poaceae & a & $\mathrm{T}$ & 20 & 0.7 & 0.66 \\
\hline 30 & Digitaria sanguinalis L. & Poaceae & a & $\mathrm{T}$ & 20 & 0.6 & 0.57 \\
\hline 31 & Digitaria ternata Stapf. & Poaceae & a & $\mathrm{T}$ & 32.5 & 1.06 & 1.03 \\
\hline 32 & Digitaria velutina Forssk. & Poaceae & a & $\mathrm{T}$ & 15 & 0.66 & 0.62 \\
\hline 33 & Echinochloa crusgalli L. & Poaceae & a & $\mathrm{T}$ & 40 & 1.6 & 1.52 \\
\hline 34 & Echinochloa colona L. & Poaceae & a & $\mathrm{T}$ & 20 & 0.86 & 0.81 \\
\hline 35 & Eleusine indica L. & Poaceae & a & $\mathrm{T}$ & 20 & 0.8 & 0.95 \\
\hline 36 & Eragrostis cilianensis All & Poaceae & a & $\mathrm{T}$ & 35 & 1.06 & 1.03 \\
\hline 37 & Eriochloa fatmensis Hochst & Poaceae & a & $\mathrm{T}$ & 20 & 0.66 & 0.81 \\
\hline 38 & Euphorbia hetrophylla L. & Euphorbiaceae & a & $\mathrm{He}$ & 20 & 0.76 & 0.82 \\
\hline 39 & Euphorbia hirta L. & Euphorbiaceae & a & $\mathrm{Hp}$ & 30 & 1.2 & 1.12 \\
\hline 40 & Euphorbia indica Lam. & Euphorbiaceae & a & $\mathrm{He}$ & 25 & 1.2 & 1.12 \\
\hline 41 & Euphorbia thymifolia Carter & Euphorbiaceae & a & Нр & 22.5 & 0.86 & 0.81 \\
\hline 42 & Galansoga parviflora Cav. & Asteraceae & A & $\mathrm{He}$ & 20 & 1.2 & 0.74 \\
\hline 43 & Guizotia scabra Vis & Asteraceae & $\mathrm{a}$ & $\mathrm{He}$ & 35 & 1.2 & 0.74 \\
\hline 44 & Heliotropium cinersis DC & Boraginaceae & a & Hs & 20 & 0.86 & 0.67 \\
\hline 45 & Indigofera spicata Forssk & Fabaceae & $\mathrm{p}$ & HR & 10 & 0.46 & 0.43 \\
\hline 46 & Ipomoea acuminate L & Convolvulaceae & a & $\mathrm{Hc}$ & 15 & 0.5 & 0.48 \\
\hline 47 & Ipomoea congesta L. & Convolvulaceae & a & $\mathrm{Hp}$ & 22.5 & 0.6 & 0.51 \\
\hline 48 & Ipomoea cordofana (Desr) & Convolvulaceae & a & $\mathrm{Hp}$ & 30 & 1.06 & 1.02 \\
\hline 49 & Ipomoea herderifolia Vatke & Convolvulaceae & a & $\mathrm{He}$ & 27.5 & 0.9 & 0.93 \\
\hline 50 & Lantana camara L. & Verbenaceae & $\mathrm{p}$ & Hs & 32.5 & 0.76 & 0.71 \\
\hline 51 & Leucas martinicensis (Jacq.) & Labiatae & $\mathrm{a}$ & $\mathrm{He}$ & 20 & 0.66 & 0.69 \\
\hline 52 & Matricaria chamomilla L. & Asteraceae & $\mathrm{a}$ & $\mathrm{He}$ & 22.5 & 0.86 & 0.81 \\
\hline 53 & Mentha arvensis L. & Labiatae & $\mathrm{a}$ & $\mathrm{He}$ & 22.5 & 0.9 & 1.01 \\
\hline 54 & Mercurialis annua L. & Convolvulaceae & $\mathrm{a}$ & Hc & 17.5 & 0.76 & 0.66 \\
\hline 55 & Nicandra physaloides L. & Solanaceae & $\mathrm{He}$ & HR & 12.5 & 0.66 & 0.54 \\
\hline 56 & Oplismenus hirtellus L. & Poaceae & $\mathrm{p}$ & HR & 15 & 0.86 & 0.62 \\
\hline 57 & Orobanche minor Smith & Orobanchaceae & $\mathrm{a}$ & & 12.5 & 0.9 & 0.77 \\
\hline 58 & Oxalis corniculata L. & Oxalidaceae & $\mathrm{p}$ & HR & 15 & 0.7 & 0.59 \\
\hline 59 & Oxygonum sinuatum Meisn & Polygonaceae & $\mathrm{a}$ & Hs & 30 & 1.24 & 1.19 \\
\hline 60 & Panicum maximum Jacq. & Poaceae & $\mathrm{p}$ & $\mathrm{T}$ & 25 & 1.06 & 1.05 \\
\hline 61 & Parthenium hysterophorus L. & Asteracae & a & $\mathrm{He}$ & 90 & 21 & 25.6 \\
\hline 62 & Pinpinella abyssinica L. & Ampiliferae & $\mathrm{a}$ & $\mathrm{He}$ & 7.5 & 0.3 & 0.28 \\
\hline 63 & Plantago lanceolata L. & Plantaginaceae & $\mathrm{p}$ & $\mathrm{He}$ & 7.5 & 0.36 & 0.30 \\
\hline 64 & Phyllanthus amarus & Euphorbiaceae & a & $\mathrm{He}$ & 22.5 & 0.6 & 0.71 \\
\hline 65 & Polygonum salicifolium Willd & Polygonaceae & a & $\mathrm{He}$ & 30 & 0.96 & 0.91 \\
\hline 66 & Rhyncossia malacophylla L. & Fabaceae & a & $\mathrm{Hc}$ & 15 & 0.6 & 0.57 \\
\hline 67 & Rumex abyssinicus Jacq & Polygonaceae & a & $\mathrm{He}$ & 10 & 0.4 & 0.43 \\
\hline 68 & Savignya parviflora L. & Brassicaceae & $\mathrm{a}$ & $\mathrm{He}$ & 5 & 0.36 & 0.33 \\
\hline 69 & Sonchus oleraceus L. & Asteraceae & a & $\mathrm{He}$ & 10 & 0.3 & 0.28 \\
\hline 70 & Setaria abyssinica L. & Poaceae & a & $\mathrm{T}$ & 12.5 & 0.36 & 0.4 \\
\hline 71 & Setaria pumila Poir. & Poaceae & a & $\mathrm{T}$ & 10 & 0.46 & 0.52 \\
\hline 72 & Setaria verticillata L. & Poaceae & a & $\mathrm{T}$ & 7.5 & 0.4 & 0.47 \\
\hline 73 & Sida acuta Burm.f. & Malvaceae & $\mathrm{p}$ & $\mathrm{He}$ & 15 & 0.7 & 0.78 \\
\hline 74 & Sida alba L. & Malvaceae & $\mathrm{p}$ & $\mathrm{He}$ & 12.5 & 0.66 & 0.76 \\
\hline 75 & Snowdenia polystachya Fresn & Poaceae & a & $\mathrm{T}$ & 10 & 0.6 & 0.71 \\
\hline 76 & Solanum incanum L. & Solanaceae & a & $\mathrm{He}$ & 17.5 & 0.86 & 1.01 \\
\hline 77 & Solanum nigrum L. & Solanaceae & a & $\mathrm{He}$ & 7.5 & 0.06 & 0.11 \\
\hline 78 & Sonchus asper L. & Asteracae & a & $\mathrm{He}$ & 15 & 0.56 & 0.65 \\
\hline
\end{tabular}




\begin{tabular}{lllllcccl}
79 & Sorghum arundinacieum Desv & Poaceae & a & $\mathrm{He}$ & 27.5 & 1.06 & 1.25 \\
80 & Spergula arvensis L & Caryophyllceae & $\mathrm{a}$ & $\mathrm{He}$ & 22.5 & 0.8 & 0.95 \\
81 & Stellaria media L. & Caryophyllceae & $\mathrm{a}$ & $\mathrm{He}$ & 15 & 0.5 & 0.59 \\
82 & Tribulus terrestris L. & Zygophyllaceae & $\mathrm{a}$ & $\mathrm{Hp}$ & 17.5 & 0.8 & 0.95 \\
83 & Trifolium sp & Fabaceae & $\mathrm{a}$ & $\mathrm{Hp}$ & 12.5 & 0.7 & 0.75 \\
84 & Trichodesma zeylanicum L. & Boraginaceae & $\mathrm{a}$ & $\mathrm{He}$ & 17.5 & 0.84 & 0.66 \\
85 & Xanthium strumarium L. & Asteracae & $\mathrm{a}$ & $\mathrm{He}$ & 45 & 4.8 & 4.53 \\
\hline
\end{tabular}

Key: $L C=$ life cycle $; H=$ growth habit $F=$ frequency; $A=$ abundance; $D=$ dominance; $c=$ climbing; $p=$ prostrate $; a=$ annual; $b=$ biennial; $p=$ perennial $H=$ herb $; e$ =erect $s=$ sprawling; $R=$ rizomateous; and $T=$ tuftted.

Table 2: Number and proportion of plant species within the six top diverse families in five locations

\begin{tabular}{lcc}
\hline \multicolumn{1}{c}{ Family } & Number of species & Percent flora \\
\hline Poaceae & 21 & 25 \\
Asteraceae & 11 & 13 \\
Fabaceae & 7 & 8 \\
Convolvulaceae & 7 & 8 \\
Solanaceae & 5 & 6 \\
Euphorbiaceae & 5 & 6 \\
\hline Total & 56 & 66 \\
\hline
\end{tabular}

In this study, six families contributed $66 \%$ of species to the total flora. Poaceae, Fabaceae, Asteraceae, and Euphorbiaceae were by far the species richest taxa and accounted together (55\%) of the entire flora of the study area (Table 2). At the genuslevel, diversity is almost two times higher than at the family level; 63 taxa have been recorded, $11 \%$ of them include three or more species, the genus Digitaria and Ipomoea being the most diverse taxa each with five species (Table 1).

\section{The frequency, Abundance and Dominance of plant species}

Averaged over locations, the frequency value of the species ranged from 5-90\%. The highest frequency value $(90 \%)$ recorded by Parthenium hyterophorus followed by Cassia tora (55\%), Cynodon dactylon (52.5\%), Argemone mexicana (47.5\%), Xanthium strumarium and Digitaria abyssinica (45\%). Whereas, the least frequency value recorded from Savignya parviflora (5\%) followed by Solanum nigrum, Setaria verticillata and Pinpinella abyssinica that recorded (7.5\%) (Table 1). This suggests that Parthenium hysterophorus is the most frequent species in the study area.

The abundance value of the species varied from 0.06 to 21 plants $\mathrm{m}^{-2}$. The highest abundance value ( 21 plants $\mathrm{m}^{-2}$ ) was recorded by Parthenium hyterophorus followed by Cassia tora ( 6.36 plants $\left.\mathrm{m}^{-2}\right)$, Argemone mexicana $\left(5.1\right.$ plants $\left.\mathrm{m}^{-2}\right)$, Xanthium strumarium $\left(4.8\right.$ plants $\left.\mathrm{m}^{-2}\right)$ and Digitaria abyssinica $\left(4.35\right.$ plants $\left./ \mathrm{m}^{2}\right)$. Whereas, the least abundance value $\left(0.06\right.$ plants $\left.\mathrm{m}^{-2}\right)$ was recorded for Solanum nigrum followed by Datura anoxia $\left(0.26\right.$ plants $\left.\mathrm{m}^{-2}\right)$, Pimpinella abyssinica, Sonchus oleraceus and Datura stramonium that recorded 0.30 plants $\mathrm{m}^{-2}$ (Table 1). This result also showed that Parthenium hysterophorus is the most abundant species in the study area suggesting its high competitiveness to the herbaceaous plant community in the area.

The range of dominance value of the species varied from $0.11-25.6 \%$. The highest dominant species was Parthenium hyterophorus followed by Cassia tora (6.07\%), Argemone mexicana (5.83\%), Xanthium strumarium (4.53\%) and Digitaria abyssinica $(4.02 \%)$. The species with the least dominance value was Solanum nigrum $(0.11 \%)$ followed by Datura inoxia $(0.2 \%)$, Pinpinella abyssinica, Sonchus oleraceus and Datura stramonium that recorded $(0.28 \%)$. Hence, the dominance values of the species composition also showed that Parthenium hysterophorus is to be the most competitive species in the area (Table 1).

Similar result was found from Tamado (2001) reported that if the specific plant species had higher frequency and dominance value, it indicate the economic importance of it. Taye (2002) stated that Parthenium hysterophorus has become a major weed of crops in northern and eastern regions of Ethiopia. Farmers in the study area reported that parthenium compete with their crop and reduce crop yields. Besides, it increases the cost of labor and other production inputs. Reports in India also indicated that parthenium significantly inhibit germination and growth of crop plants, heavy pollen deposits on nearby crop resulted in failure of seed set and caused yield loss up to $40 \%$ on maize (Navie et al., 2004). Therefore, this study confirmed that parthenium is one of the major social, environmental and economic threats in the study area.

In general, there were positive and significant correlations among frequency, abundance and dominance, that is the higher the frequency of the weed species, the higher will be its abundance and dominance and vice versa. The higher frequency, abundance and dominance values of Cassia tora, Argemone mexicana, Xanthium strumarium and Digitaria abyssinica suggest that these species can grow in competition with parthenium. Moreover, the competitiveness of these species with parthenium, in the long run, might be greater and may serve as a replacement tool for the management of parthenium in the parthenium infested areas with similar ecological conditions. Hence, as a continuation of the field survey, a greenhouse study was made in order to evaluate the competitiveness of these species versus parthenium at different density proportions. 
Figure 1: Frequency, Abundance and Dominance of the top seven plants in 2008

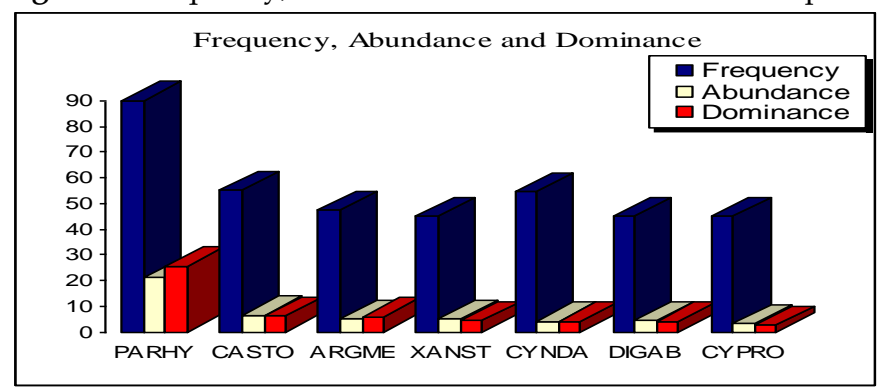

Key: $\mathrm{PARHY}=$ Parthenium hysterophorus, $\mathrm{DIGAB}=$ Digitaria abyssinica, $\mathrm{CASTO}=$ Cassia tora, $\mathrm{ARGME}=$ Argemone mexicana, $\mathrm{XANST}=$ Xanthium strumarium, CYNDA = Cynodon dactylon, $\mathrm{CYPRO}=$ Cyperus rotundus

\section{Similarity Index}

Similarity index is the similarity of plant species composition among different PAs in Boset district. The result showed a similarity index value of $65-78 \%$ among the PAs (Table 3). This suggests that the plant species composition among the different PAs were similar by $65-78 \%$. As described by Yohannes and Taye (1999), if the index of similarity is below $60 \%$, it is said that the two locations or soil types have different weed communities. Since similarity indices for the different location were greater than $60 \%$ it can be concluded that the locations exhibited similar weed community and thus, require similar management options.

Table 3: Similarity index of herbaceous plant community in the five PAs of Boset district

\begin{tabular}{lccccc}
\hline Locations & Xiyoo & Digelu & Tri Biretii & Tsedecha & Borchota \\
\hline Xiyoo & 100 & 78 & 76 & 74 & 67 \\
Digelu & & 100 & 72 & 71 & 65 \\
Tri Biretii & & & 100 & 74 & 67 \\
Tsedecha & & & & 100 & 78 \\
Borchota & & & & & 100 \\
\hline
\end{tabular}

\section{Species diversity and evenness}

The diversity and evenness of species were not significantly different among different study sites or PAs which was analyzed by McCune and Meffored softwear 1999 (Table 4). The highest mean number (3.73) of the diversity was obtained in Tsedecha site while the lowest mean number (2.65) was obtained at Tri briti site. The higher value of the diversity index indicates the variation in the type of species and heterogeneity in the communities where as the lesser values indicate the homogeneities of the species and the lower diversity of species. According to table 4 , the high mean value of (0.87) evenness was observed at Tsedecha and least mean value of (0.65) evenness was obtained at Tri-briti site. The diversity and evenness of species were positively associated. The higher species diversity, the greater would be the evenness. The present study revealed that the diversity and evenness of species declined with increasing spread of parthenium since parthenium dominance is high at Tri-briti (37) than Tsedech (18). This suggests the negative influence that parthenium had on the status of species diversity in the studied sites of Boset district. This finding about the mean number of diversity was consistent to those revealed in the study done by Navie et al. (2004). In their studies, the authors pointed out that the diversity values depend on the dominance of the parthenium weed in the community and it may reduce the diversity of weed species. It is possible that the persistence infestation of parthenium in the study area might have contributed to low plant species diversity and evenness values at Tri-briti.

Table 4: Species diversity and evenness in different study sites

\begin{tabular}{lll}
\hline Locations & Diversity & Evenness \\
\hline Xiyoo & $3.03 \pm 0.97 \mathrm{a}$ & $0.72 \pm 0.04 \mathrm{a}$ \\
Digelu & $3.04 \pm 0.97 \mathrm{a}$ & $0.73 \pm 0.04 \mathrm{a}$ \\
Tri Biretii & $2.65 \pm 0.97 \mathrm{~b}$ & $0.65 \pm 0.04 \mathrm{~b}$ \\
Tsedecha & $3.73 \pm 0.97 \mathrm{a}$ & $0.87 \pm 0.04 \mathrm{a}$ \\
Borchota & $3.70 \pm 0.97 \mathrm{a}$ & $0.85 \pm 0.04 \mathrm{a}$
\end{tabular}

Note: - Means of the same letters are not significantly $(\mathrm{p}<0.05)$ different from each other

Distribution and Importance of Parthenium on other Weed Species

Parthenium showed varied level of infestation (dominance) that ranged from $18 \%$ to $37.3 \%$ in the surveyed five PAs in the study area. Among the study Kebles, severe infestation of parthenium was scored for Tri-bretii PAs (37.3\%) followed by Borchota (33.8\%) but the lowest infestation scored at Tsedech (18\%) followed by Xiyoo (18.8\%). 
Almost all PAs were observed to be infested with parthenium. Thus, among these PAs, parthenium had a significant importance on distribution and level of native biodiversity (Figure 5). In line with this, studies conducted in different parts of the country indicated that parthenium had different distribution and importance level (Taye, 2002; Rezene, 2005; Besufekad et al., 2005).

Figure 2: Distribution and infestation level of parthenium in five PAs at Boset district

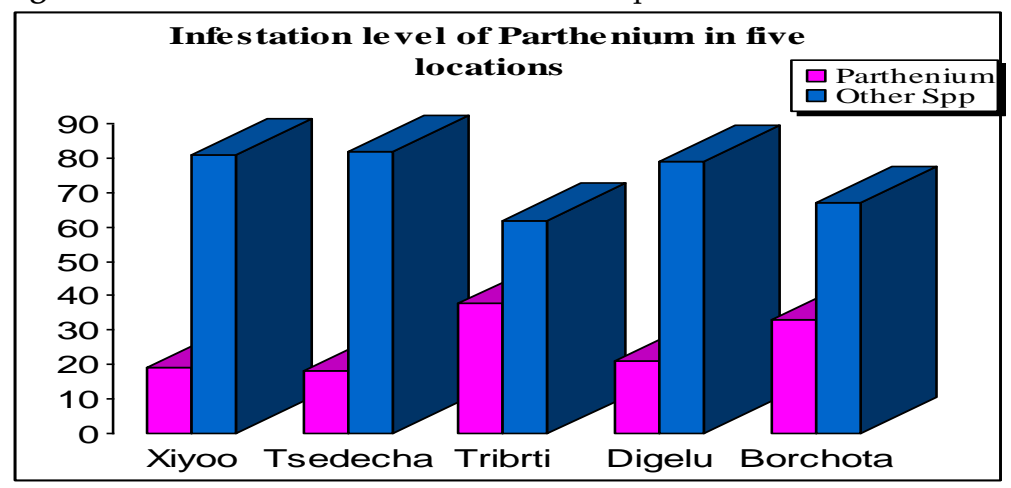

On the other hand, parthenium infestation level showed significant effect on the level of other plant species grown in the study area. In Tri-birtii PAs there is high level of parthenium infestation and low plant diversity showed as compared to Tsedecha PAs that showed low density of parthenium and high plant diversity (figure 2). This shows that there is a trend of change in plant composition as a result of parthenium dominance and it agrees with the reports of different authors that showed parthenium had a significant effect on plant diversity in a given eco-system (Jayachandra, 1971; McFadyne, 1992; Chippendale and Panetta, 1994; Evans, 1997; Taye, 2002). Hence, all the PAs in the district need to have strong preventive and control strategy and implementation in order to save existing biodiversity.

\section{SUMmaRY AND CONCLUSION}

Parthenium became a weed of economic importance in Ethiopia during the past 10-15 years. It is still spreading rapidly and has had a substantial problem on crop and animal production, biodiversity, human and animal health. Therefore, development of effective prevention and control programs are very essential to overcome its problems. No single method of control has been proved satisfactory. Hence, there is a need to adopt an integrated parthenium management approach by amalgamating more than one option. Among these, use of strong interfering competitor plants is recommended as component of integrated parthenium management. Thus, identification and selection of strong competitive plant species which grow with parthenium and determination of their competitiveness was designed to aid future implementation of biological control of parthenium.

Based on the study, the total of eighty five different herbaceous plant species was identified. The importance of each species was determined by calculating the frequency, abundance and dominance values. The major plant species having a dominance level greater than 3\% were Parthenium hysterophoru (25.6), Cassia tora (6.07), Argemone mexicana (5.83), Xanthium strumarium (4.53), Digitaria abyssinica (3.02) and Cyperus rotundus (2.86). In general, three herbaceous species, namely Cassia tora, Xanthium strumarium and Argemone mexicana had good association and grow with Parthenium hysterophrous in competition. They have relatively high abundance and dominance value as well as potential to compete with $P$. hysterophorus as they had large area coverage in the study site. Therefore, these species are recommended for Parthenium eradication.

\section{REFERENCES}

Aneja, K.R., Kaur, M., and Sharma, A. 1994. Leaf spot disease of Parthenium hysterophorus: a new disease record. National Academy of Science Letters 17: 79-180.

Besufekad T.,T.K.Das, M.Mahaderappa, Taye, T., and Tamado, T. 2005. Parthenium distribution, biology, hazards, and control measures in Ethiopia. Pest Management Journal of Ethiopia. 9: 1-15

Bhan VM, S Kumar, and MS Raghuwanshi 1997. Future Strategies for Effective parthenium management. In: Mahadevappa, M. and VC pail (eds.). Proceedings of the $1^{\text {st }}$ International Conference on Parthenium Management, 6-8 October 1997, University of Agricultural Sciences, Dahrwad, Karnataka, India, pp 90-95.

Chippendale, J.F.; Panetta, F.D. 1994. The cost of parthenium weed to the Queens-land cattle industry. Plant Protection Quarterly 9, 73-76. Ciba-Geigy. 1980. Grass weeds 1. Ciba-Geigy Ltd., Basle, Switzerland.

Debela Hunde, Zemede Asfaw And Ensermu Kelbessa. 2004. Use and Management of Ethno veternary Medicinal Plants By Indigenous People In Boset Welenchiti Area. Ethiopian Journal of Biological Science, 3(2), 113-132.

Evans, H.C., 1997. Parthenium hytsterophorus L: a review of its weed status and the possibilities for biological control. Biocontrol News and Information, 18:89-98 
Firehun, Y. and Tamado, T. 2006. Qualitative and quantitative assessment of weeds in flora of Sugar cane plantations of WonjiShoa and Metahara. Ethiopian Journal of Weed Management 1:1-13

Frew, M., Solomon, K., and Mashilla, D.1996. prevalence and distribution of Parthenium hysterophorus L. in eastern Ethiopia. Arem 1:19-26

Gessesse AT and Berhe AA. 2014. Effect of In-situ Rainwater Conservations and Sowing Date on Barley Yield and Weed Infestation: A Case study at Maychew and Mekelle, Northern Ethiopia. Malaysian Journal of Medical and Biological Research, 1, 128-134.

Hill, M. O., 1973. Diversity and its evenness, a unifying notation and its consequences. J. of Ecology, 54:427-432.

Jayachandra. 1971. Parthenium weed in Mysore State and its control. Current Science 40: 568-569.

McCune, B. and Meffored, M.J. 1999. Multiviate analysis of ecological data version 4.20, MjM softwear, Gleneden Beach, Ore, Orgen USA.

McFadyen, R.E. 1992. Biological control against parthenium weed in Australia. Crop Protection 11:400-407.

Navie, S.C.; McFadyen, R.E.; Panetta, F.D.; Adkins, S.W. 2004. The biology of Australian weeds 27. Parthenium hysterophorus L. Plant Protection Quarterly 11: 76-88.

Rezene T., Mekasha C., and Mengistu H.G. 2005. Spread and consequences of Parthenium hytsterophorus L. in Ethiopia. Arem, Ethiopian Weed Science Society 6:15-16

Shannon, C. E., and W. Weaver. 1963. The Mathematical Theory of Communication. Urbana,I.L: University of Illinois Press. pp. 31-35.

Silva, J., Nicácio, S., \& Silva, A. (2014). Work on behalf of Native Forest Conservation in the Settlements Pacas and Paraná, Murici and Girau Do Ponciano Municipalities, State of Alagoas, Northeastern Brazil. Asian Journal Of Applied Science And Engineering, 3(4), 34-40. Retrieved from http://journals.abc.us.org/index.php/ajase/article/view/8.4

Singh, S.P. 1997. Prospective in biological control of Parthenium in India. In: Mahadevappa, M., and Patil, V.C. (eds), Proceedings of the1st International Conference on Parthenium Management, 6-8 October 1997, University of Agricultural Sciences, Dahrwad, India, 22-32.

Tamado, T., 2001. Biology and management of parthenium (Parthenium hysterophorus L.) in Ethiopia. Ph.D. thesis. Swedish University of Agricultural Sciences, Uppsala

Tamado, T., and P. Milberg. 2002. Weed flora in arable fields of eastern Ethiopia with emphasis on the occurrence of Parthenium hytsterophorus L. Weed Research 40: 507-521

Taye T. 2002. Investigation of pathogens for biological control of parthenium (Parthenium hysterophorus L) in Ethiopia. Ph.D. thesis. Humboldt University of Berlin, Berlin, Germany. C. obermeir G. Einhorn, E. Seemuller, and Butlner.

Taye, T., L. Yohannes, and A. Belayneh. 1998. Qualitative and quantitative determination of weed occurrence in wheat in west Shewa zone of Ethiopia. $10^{\text {th }}$ regional wheat workshop for eastern, central and southern Africa. Sept. 14-18, 1998, University of Stellenbosch, South Africa, pp 160-172.

Wittenberg, R. 2004. Instruments and tools for assessing the impact of invasive plant species in Africa. Report submitted under the PDF-B phase of the UNEP/GEF Project: Removing Barriers to Invasive Plant Management in Africa. CABI Africa Regional Center, Nairobi, Kenya.

Yohannes L., and Taye, T. 1999. Incidence and distribution of Striga spp in Ethiopia. Ethiopian Weed Science Society $4^{\text {th }}$ Annual Conference, 3-4 April 1999, Addis Ababa, Ethiopia. 